\title{
ANALISIS KESADARAN WAJIB PAJAK DALAM TRANSAKSI E- COMMERCE (STUDI KASUS WAJIB PAJAK ORANG PRIBADI (WPOP) YANG MERUPAKAN PELAKU E-COMMERCE DI KOTA DKI JAKARTA
}

\author{
Tries Handriman Jamain \\ Fakultas Ekonomi dan Bisnis, Universitas Sahid \\ Jl. Soepomo No 84, Tebet, Jakarta Selatan \\ Email Korespondensi: trieshandrimanjamain@gmail.com
}

\begin{abstract}
ABSTRAK
Salah satu jenis implementasi teknologi dalam hal meningkatkan persaingan bisnis dan penjualan produk produk adalah dengan menggunakan electronic commerce (e-commerce) untuk memasarkan berbagai macam produk atau jasa, baik dalam bentuk fisik maupun digital. Melihat pertumbuhan e-Commerce yang meningkat tajam tentunya hal tersebut merupakan peluang besar Indonesia untuk meningkatkan penghasilan negara terutama dibagian perpajakan. Para pelaku eCommerce tentunya diwajibkan dikenakan Pajak Penghasilan $(\mathrm{PPh})$ atas transaksi e-Commerce yang dilakukan. Tujuan penelitian ini adalah menganalisis Kesadaran Wajib Pajak pada orang pribadi dalam Transaksi E-Commerce pada wajiba pajak orang pribadi yang ada di Kantor pajak Jakrat. Metode penelitian yang digunakan adalah metode deskriptif. Sedangkan data yang digunakan dalam penelitian ini yakni data primer, dimana data diperoleh dengan secara langsung turun kelapangan dari sumbernya dan jenis data ini memerlukan pengolahan yang lebih lanjut. Seluruh Wajib Pajak orang pribadi yang merupakan pelaku e-Commerce di Kota DKI Jakarta yang diperkirakan sejumlah lebih dari 1.000 Orang Pribadi akan dijadikan populasi didalam penelitian ini. Hasil penelitian bahwa tingkat Kesadaran Pelaku E-Commerce yang Rendah Selaku Wajib Pajak berpengaruh signifikan terhadap penghambat pengenaan pajak penghasilan karena didapat tingkat signifikan
\end{abstract}

Kata kunci : Kesadaran Wajib Pajak, Transaksi, E-Commerce

\begin{abstract}
One type of technology implementation in terms of increasing business competition and product sales is to use electronic commerce (e-commerce) to market a variety of products or services, both in physical and digital forms. Seeing the growth of e-Commerce has increased sharply, of courses this is a great opportunity for Indonesia to increase state income, especially in the taxation sector. The e-Commerce actors are certainly required to be subject to Income Tax (PPh) for e-Commerce transactions conducted. The purpose of this study was to analyze taxpayers' awareness of individuals in the E-Commerce Transaction on personal tax returns at the Jakrat tax office. The method used is descriptive method. While the data used in this study is primary data, where data is obtained by directly descending space from the source and this type of data requires further processing. All individual taxpayers who are e-Commerce actors in the city of DKI Jakarta who are estimated to number more than 1,000 private persons will be made into the population in this study. Low E-Commerce Actors' Awareness Levels As Taxpayers have a significant effect on income tax imposition because there is a significant level
\end{abstract}

Keyword : Taxpayer Awareness, Transactions, E-Commerce 


\section{PENDAHULUAN}

Pajak adalah suatu hal yang penting bagi suatu Negara, Negara tidak akan mampu berjalan untuk membiayai pemerintahan dan infrastruktur Negara tersebut. Maka sangat dibutuhkan pengelolaan pajak dengan baik dan maksimal sehingga bisa mendapatkan hasil yang maksimal juga. Ketika hasil yang maksimal maka akan dapat membantu pendapatan dan devisa suatu Negara, ketika pendapatan dari pajak maksimal maka akan mampu penyaluran pertumbuhan dan pembangunan infrastruktur yang baik di Negara tersebut.

Untuk meningkatkan pendapatan dari sektor pajak baik migas dan non migas maka pemerintah melakukan beberapa kebijakan yaitu dengan mengeluarkan suatu program online bagaimana pihak wajib pajak tidak repot dan tidak merasa terbebanin untuk melakukan pembayaran pajak, dan pihak wajib pajak bisa membayar pajak dimana dan kapanpun. Ada pun program online yang diluncurk an oleh pemerintah adalah e-SPT dan e-Filing. Dengan Sofware program online e-SPT dan e-Filing maka akan meningkatkan kinerja dari Fiskus dan kesadaran Wajib pajak. Sejalan dengan cepatnya perkembangan bidang teknologi, perusahaan-perusahaan makin dipacu untuk menggunakan teknologi yang maju sebagai senjata untuk tetap survive dan memenangkan persaingan yang kian hari terasa ketat dan keras. Akhir-akhir ini penggunaan internet yang menjurus kepada cyberspace kelihatannya akan mendominasi seluruh kegiatan di atas permukaan bumi di masa kini dan masa datang dan secara umum akan berubah menjadi alat untuk persaingan antara perusahaan yang satu dengan yang lainnya. Ini pun akan membawa dampak yang sangat besar bagi setiap perusahaan. Dampak pada aspek persaingan adalah terbentuknya tingkat kompetisi yang semakin tajam. Globalisasi ekonomi juga membuat perubahan menjadi konstan, pesat, radikal, serentak, dan pervasif. Sehingga perusahaan harus memiliki kemampuan yang cepat untuk beradaptasi terhadap perubahan yang terjadi sehingga perusahaan akan mampu bersaing dengan para kompetitornya.

Penggunaan teknologi diharapkan dapat memberikan manfaat yang besar terhadap dunia bisnis yang kompetitif tersebut. Perusahaan yang mampu bersaing dalam kompetisi tersebut adalah perusahaan yang mampu mengimplementasikan teknologi ke dalam perusahaannya. Salah satu jenis implementasi teknologi dalam hal meningkatkan persaingan bisnis dan penjualan produk produk adalah dengan menggunakan electronic commerce (e-commerce) untuk memasarkan berbagai macam produk atau jasa, baik dalam bentuk fisik maupun digital. Dalam penggunaan teknologi tersebut, berbagai pihak yang terkait dengan perusahaan seperti investor, konsumen, pemerintah akan ikut berperan. Menurut survei yang dilakukan oleh Lembaga Riset pasar e-Marketer dari tahun 2014 - 2018, Indonesia menduduki posisi ke-6 dari 10 besar negara di dunia sebagai pengguna internet.

\begin{tabular}{|c|c|c|c|c|c|c|}
\hline & 2013 & 2014 & 2015 & 2016 & 2017 & 2018 \\
\hline 1. China* & 620.7 & 643.6 & 669.8 & 700.1 & 736.2 & 777.0 \\
\hline 2. Us* & 246.0 & 252.9 & 259.3 & 264.9 & 269.7 & 274.1 \\
\hline 3. India & 167.2 & 215.6 & 252.3 & 283.8 & 313.8 & 346,3 \\
\hline 4. Brazil & 99.2 & 107.7 & 113.7 & 119.8 & 123.3 & 125.9 \\
\hline 5. Japan & 100.0 & 102.1 & 103.6 & 104.5 & 105.0 & 105.4 \\
\hline 6. Indonesia & 72.8 & 83.7 & 93.4 & 102.8 & 112.6 & 123.0 \\
\hline 7. Russia & 77.5 & 82.9 & 87.3 & 91.4 & 94.3 & 96.6 \\
\hline 8. Germany & 59.5 & 61.6 & 62.2 & 62.5 & 62.7 & 62.7 \\
\hline 9. Mexico & 53.1 & 59.4 & 65.1 & 70.7 & 75.7 & 80.4 \\
\hline 10. Nigeria & 51.8 & 57.7 & 63.2 & 69.1 & 76.2 & 84.3 \\
\hline 11. UK * & 48.8 & 50.1 & 51.3 & 52.4 & 53.4 & 54.3 \\
\hline 12. France & 48.8 & 49.7 & 50.5 & 51.2 & 51.9 & 52.5 \\
\hline 13. Philippines & 42.3 & 480 & 537 & 59.1 & 64.5 & 69.3 \\
\hline
\end{tabular}

\begin{tabular}{|c|c|c|c|c|c|c|}
\hline 14. Turkey & 36.6 & 41.0 & 44.7 & 47.7 & 50.7 & 53.5 \\
\hline 15. Vietnam & 36.6 & 40.5 & 44.4 & 48.2 & 52.1 & 55.8 \\
\hline 16. South Korea & 40.1 & 40.4 & 40.6 & 40.7 & 40.9 & 41.0 \\
\hline 17. Egypt & 34.1 & 36.0 & 38.3 & 40.9 & 43.9 & 47.4 \\
\hline 18. Italy & 34.5 & 35.8 & 36.2 & 37.2 & 37.5 & 37.7 \\
\hline 19. Spain & 30.5 & 31.6 & 323 & 33.0 & 33.5 & 33.9 \\
\hline 20. Canada & 27.7 & 28.3 & 28.8 & 29.4 & 29.9 & 30.4 \\
\hline 21. Argentina & 25.0 & 27.1 & 29.0 & 29.8 & 30.5 & 31.1 \\
\hline 22. colombia & 24.2 & 26.5 & 28.6 & 29.4 & 30.5 & 31.3 \\
\hline 23. Thailand & 22.7 & 24.3 & 26.0 & 27.6 & 29.1 & 30.6 \\
\hline 24. Poland & 22.6 & 22.9 & 23.3 & 23.7 & 24.0 & 24.3 \\
\hline 25. South Africa & 20.1 & 22.7 & 25.0 & 27.2 & 29.2 & 30.9 \\
\hline \multicolumn{2}{|c|}{ Worldwide *N 2.692 .9} & $2,892.7$ & 3.072 .6 & 3.246 .3 & 3.419 .9 & $3,600.2$ \\
\hline \multicolumn{7}{|c|}{ 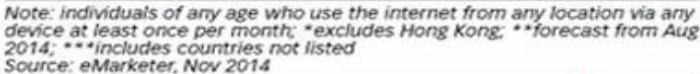 } \\
\hline
\end{tabular}

Gambar 1.1. Top 25 Negara Pengguna Internet di Dunia Sumber : https://kominfo.go.id 
Hal itu dibuktikan oleh hasil riset e-Marketer dan dikembangkan oleh databoks katadata yang menunjukkan bahwa volume nilai transaksi e-Commerce di Negara Indonesia mencapai hingga menembus angka Rp. 108,4 T di tahun 2017, dan di tahun 2018, volume nilai transaksi e-Commerce di Negara Indonesia diperkirakan terus meningkat mencapai hingga menembus angkaRp 144,1 T.

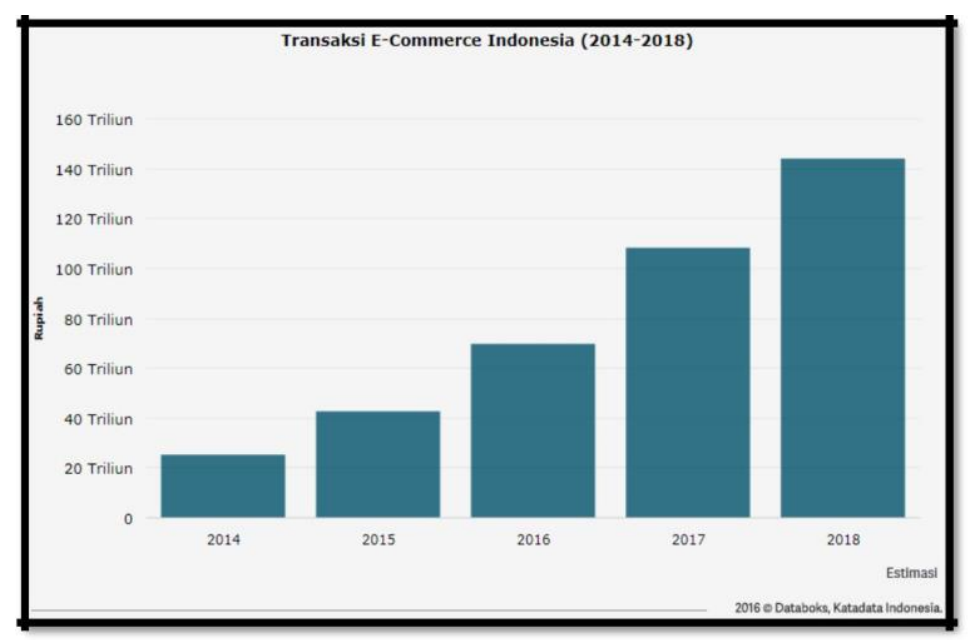

Gambar 1.2. Grafik Transaksi E-Commerce di Indonesia Sumber : $\underline{\text { https://databoks.katadata.co.id }}$

Melihat pertumbuhan e-Commerce yang meningkat tajam tentunya hal tersebut merupakan peluang besar Indonesia untuk meningkatkan penghasilan negara terutama dibagian perpajakan. Para pelaku e-Commerce tentunya diwajibkan dikenakan Pajak Penghasilan $(\mathrm{PPh})$ atas transaksi $e$-Commerce yang dilakukan.

Maka dari hasil data sementara di atas menunjukkan betapa besarnya keuntungan dari pungutan pajak ketika di berlakukan patuh pajak terhadap wajib pajak orang pribadi yang mengunakan transaksi e-Commerce, dan hasil dari pungutan pajak itu sangat membantu pendapat Negara dari bidang pajak, hal itu dapat kita lihat dari tahun ke tahun pendapatan Negara yang bersumber dari pajak semakin naik.

Tujuan penelitian ini adalah menganalisis Kesadaran Wajib Pajak pada orang pribadi dalam Transaksi E-Commerce pada wajib pajak orang pribadi yang ada di Kantor pajak DKI Jakarta.

\section{Wajib Pajak}

Menurut Irianto (2005) dalam Widayati dan Nurlis (2010) kesadaran bahwa pajak merupakan bentuk partisipasi dalam menunjang pembangunan Negara. Dengan menyadari bahwa hal ini, wajib pajak mau membayar pajak karena merasa tidak dirugikan dari pemungutan pajak yang dilakukan.

Kesadaran bahwa penudaan pembayaran pajak dan pengurangan beban pajak sangat merugikan negara. Wajib pajak mau membayar pajak karena memahami bahwa penundaan pembayaran pajak dan pengurangan beban pajak berdampak pada kurangnya sumber daya financial yang dapat mengakibatkan terhambatnya pembangunan negara. 
Kesadaran bahwa pajak ditetapkan dengan Undang-Undang dan dapat dipaksakan. Wajib pajak akan membayar karena pemabayaran pajak didasari memiliki landasan hukum yang kuat dan merupakan kewajiban mutlak setiap warga negara.

Menurut Waluyo (2013 :23) Wajib pajak adalah orang pribadi atau badan, meliputi membayar pajak, dan pemungut pajak, yang mempunyai hak dan kewajibanperpajakan sesuai dengan ketentuan peraturan dan perundang-undangan perpajakan.Menurut Sumarsan ( 2013 :19) Wajib Pajak adalah orang pribadi atau badan, meliputi pembayar pajak, pemotongan pajak, dan pemungut pajak, yang mempunyai hak dan kewajiban perpajakan sesuai dengan ketentuan peraturan perundang-undangan perpajakan.

\section{E-Commerce}

Electronic Commerce (e-commerce) merupakan konsep baru yang biasa digambarkan sebagai proses jual beli barang atau jasa pada World Wide Web Internet (Shim, Quershi, Siegel, Siegel, 2000 dalam buku M. Suyanto, 11, 2003) atau proses jual beli atau pertukaran produk, jasa dan informasi melalui jaringan informasi termasuk internet (Turban, Lee, King, Chung, 2000 dalam buku M. Suyanto,11,2003).

Sedangkan menurut Kalakota dan Whinston (1997) dalam buku M. Suyanto (2003) mendefinisikan e-commerce dari beberapa perspektif berikut :

1. Perspektif Komunikasi : e-commerce merupakan pengiriman indormasi, produk/layanan, atau pembayaran melalui lini telepon, jaringan computer atau sarana eletronik lainnya.

2. Perspektif Proses Bisnis : e-commerce merupakan aplikasi teknologi menuju otomisasi transaksi dan aliran kerja perusahaan.

3. Perspektif Layanan: e-commerce merupakan salah satu alat yang memenuhi keinginan perusahaan, konsumen dan manajemen dalam memangkas service cost ketika meningkatkan mutu barang dan kecepatan pelayanan.

\section{Pajak Penghasilan Atas Transaksi E-Commerce}

Direktorat Jenderal Pajak (DJP) memberikan penegasan atas transaksi e-Commerce melalui Surat Edaran nomor SE-62/PJ/2013 mengenai Penegasan Ketentuan Perpajakan atas Transaksi e-Commerce sebagai kebijakan untuk mengoptimalkan penerimaan negara atas PPh dan PPN, penegasan pajak ini dibuat sebagai salah satu upaya pemerintah untuk memberikan keadilan terhadap pengusaha yang melakukan perdagangan konvensional.

Selain itu, sesuai dengan undang-undang No. 36 Tahun 2008 Pasal 4, menyatakan bahwa yang menjadi objek pajak adalah penghasilan, yaitu setiap tambahan kemampuan ekonomis yang diterima atau diperoleh Wajib Pajak, baik yang berasal dari Indonesia maupun dari luar Indonesia, yang dapat dipakai untuk konsumsi atau untuk menambah kekayaan Wajib Pajak yang bersangkutan, dengan nama dan dalam bentuk apapun. Maka dalam hal ini, pada transaksi e-Commerce ada pembayaran imbalan atau penghasilan karena jual-beli barang/atau jasa yang merupakan objek pajak Pajak Penghasilan (PPh).

Pelaku e-Commerce Orang Pribadi diwajibkan dikenakan Pajak Penghasilan, namun masih mengkuti ketentuan pajak penghasilan secara umum. Khusus pelaku eCommerce orang pribadi, pengenaan dipersamakan dengan toko konvensional, yaitu berlakunya PP Nomor 23 tahun 2018, pajak pada pelaku/pengusaha e-Commerce dengan besarnya pendapatan bruto tidak melebihi Rp 4,8 M yaitu sama dengan pajak UMKM, tarifnya $0,5 \%$ dari omset yang diperoleh setiap bulannya. Pada awalnya, e-Commerce dilakukan hanya pada transaksi bisnis/usaha dilakukan oleh perusahaan besar, perbankan, dan institusi besar lainnya. 
Dengan melihat peningkatan situs jejaring sosial, seperti Line, Twitter, Facebook dan Instagram telah memberikan kesempatan untuk membuka usaha/bisnis yang baru (Liang, 2011 dalam Puspawati, 2016).

Perdagangan media internet atau e-Commerce bergeser mendekati konsumen individual, dimana masing-masing konsumen dapat beralih menjadi penjual dengan menawarkan kembali melalui akun media sosial yang dimiliki. Sehingga tidak hanya perusahaan besar saja yang mendapatkan keuntungan dari semakin rendahnya biaya perdagangan melalui e-Commerce, namun perusahaan-perusahaan berskala kecil, bahkan masing-masing individu juga (Nugroho, 2006 dalam Utomo, 2012). Meskipun perdagangan dilakukan secara individual, dan dilakukan secara online melalui akun media sosial seperti Facebook, Line, Twitter, Instagram, Google, BBM dan whatsApp. Berdasar pada ketentuan perpajakan yang berlaku, maka individu tersebut termasuk kedalam wajib pajak orang pribadi yang harus melakukan pembayaran pajak, karena dari kegiatan penjualan melalui akun media sosial tersebut, individu telah mendapatkan penghasilan yang diterima.

\section{METODE PELAKSANAAN}

Metode penelitian yang digunakan adalah metode deskriptif. Sedangkan data yang digunakan dalam penelitian ini yakni data primer, dimana data diperoleh dengan secara langsung turun kelapangan dari sumbernya dan jenis data ini memerlukan pengolahan yang lebih lanjut. Penelitian ini menggunakan sumber data eksternal, yakni data didapat dari menyebarkan angket atau kuesioner yang telah dijawab oleh responden Wajib Pajak Orang Pribadi (WPOP) yang merupakan pelaku e-Commerce di Kota DKI Jakarta.Dalam penelitian ini objek yang akan diteliti adalah Seluruh Wajib Pajak Orang Pribadi yang merupakan Pelaku e-Commerce di DKI Jakarta, Menurut Kuncoro (2009: 118) dalam Tiraada (2013), mengartikan bahwa populasi yakni sekelompok elemen (objek, transaksi, orang), dimana memiliki ketertarikan untuk dijadikan sabagai objek penelitian. Seluruh Wajib Pajak orang pribadi yang merupakan pelaku e-Commerce di Kota DKI Jakarta yang diperkirakan sejumlah lebih dari 1.000 Orang Pribadi akan dijadikan populasi di dalam penelitian ini. Sampel merupakan himpunan dari unit populasi, dikarenakan jumlah populasi yang begitu banyak, maka tidak semua anggota populasi akan diteliti namun menggunakan sampel dari populasi penelitian tersebut (Kuncoro, 2009: 118, dalam Tiraada, 2013). Metode pengambilan sampel yang digunakan untuk pengambilan sampel yakni convenience sampling dimana peneliti bebas memilih sampel yang mana yang ingin diambil.

Dalam penelitian ini penulis menggunakan metode Angket/Kuisioner. Menurut (Ridwan, 2008:25) Angket/Kuisioner adalah daftar pertanyaan yang diberikan kepada orang lain yang bersedia memberikan respons (responden) sesuai dengan permintaan pengguna.

\section{HASIL DAN PEMBAHASAN}

\section{Karakteristik Responden Berdasarkan Lama Menjadi Pelaku E-Commerce}

Analisis terhadap lama menjadi pelaku e-Commerce dimaksudkan untuk mengetahui berapa lama responden telah melakukan transaksi $e$-Commerce. Berdasarkan hasil penelitian, diperoleh gambaran tentang lama menjadi pelaku e-Commerce dari responden seperti pada gambar dibawah ini. 


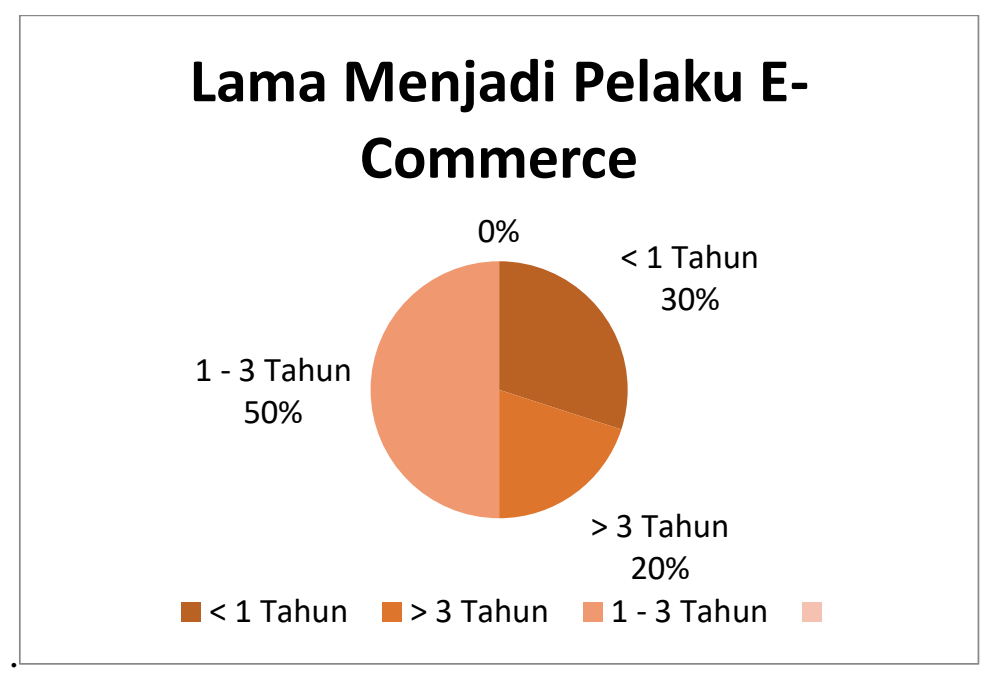

Gambar 4.1. Grafik Karakteristik Responden Berdasarkan Lama Menjadi Pelaku E-Commerce Sumber : Data Diolah Oleh Penulis, 2019.

Berdasarkan gambar diatas dapat disimpulkan bahwa dari 100 responden, responden yang telah menjadi pelaku e-Commerce selama 1-3 tahun yakni sebesar 46 responden atau $46 \%$ telah mendominasi sebagian besar transaksi e-Commerce hal itu disebabkan karena transaksi e-Commerce pada saat ini lebih mudah dilakukan,sehingga memunculkan ketertarikan orang-orang untuk menjadi pelaku $e$-Commerce. Sementara responden yang telah menjadi pelaku e-Commerce selama $>1$ tahun yakni sebesar 27 responden atau $27 \%$ responden begitu pula untuk pelaku $e$-Commerce selama $>3$ tahun yakni sebesar 27 responden atau $27 \%$.

\section{Karakteristik Responden Berdasarkan Pendapatan Pertahun}

Analisis terhadap pendapatan pertahun pelaku e-Commerce dimaksudkan untuk mengetahui berapa besar pendapatan yang diterima oleh responden dari transaksi $e$ Commerce dalam satu tahun. Berdasarkan hasil penelitian, diperoleh gambaran tentang pendapatan pertahun pelaku e-Commerce dari responden seperti pada gambar dibawah ini:

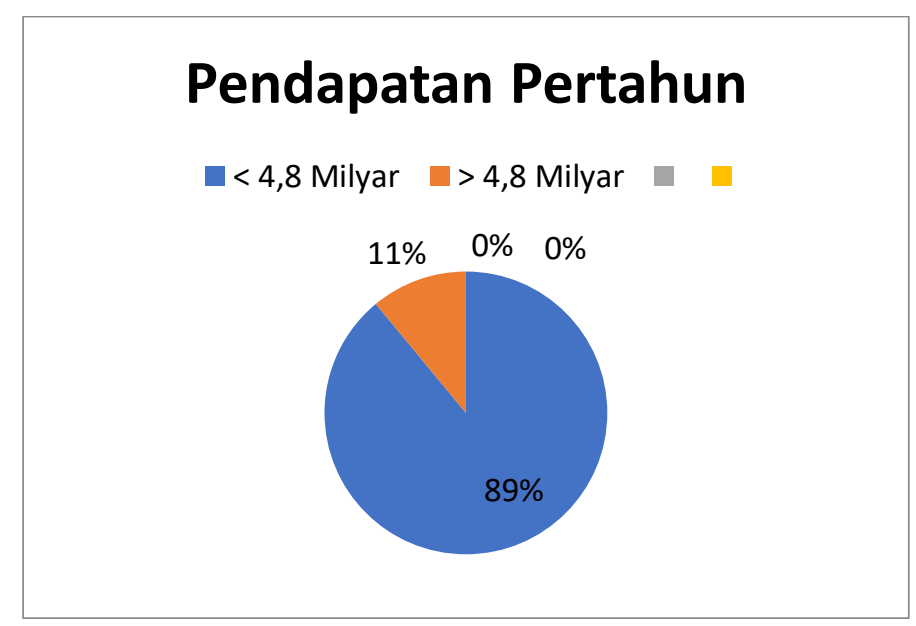

Gambar 4.2. Grafik Karakteristik Responden Berdasarkan Pendapatan Pertahun Sumber : Data Diolah Oleh Penulis, 2019. 
Sesuai dengan gambar diatas diketahui bahwa dari 100 responden yang dijadikan sampel, responden yang memiliki pendapatan pertahun <4.8 Milyar lebih banyak dibandingkan dengan responden yang memiliki pendapatan pertahun $>4.8$ Milyar. Responden dengan pendapatan pertahun < 4.8 Milyar yakni sebesar 89 responden atau 89 $\%$, dan responden dengan pendapatan pertahun $>4.8$ Milyar yakni sebesar 11 responden atau $11 \%$. Hal ini disebabkan karena transaksi e-Commerce sebagian besar dilakukan secara individual atau perorangan yangmelalui akun media sosial.

\section{Karakteristik Responden Berdasarkan Kepemilikan NPWP}

Analisis terhadap kepemilikan NPWP pelaku e-Commerce dimaksudkan untuk mengetahui berapa banyak responden yang memiliki NPWP dalam melakukan transaksi e-Commerce. Berdasarkan hasil penelitian, didapat gambaran mengenai kepemilikan NPWP dari responden seperti pada gambar dibawah ini:

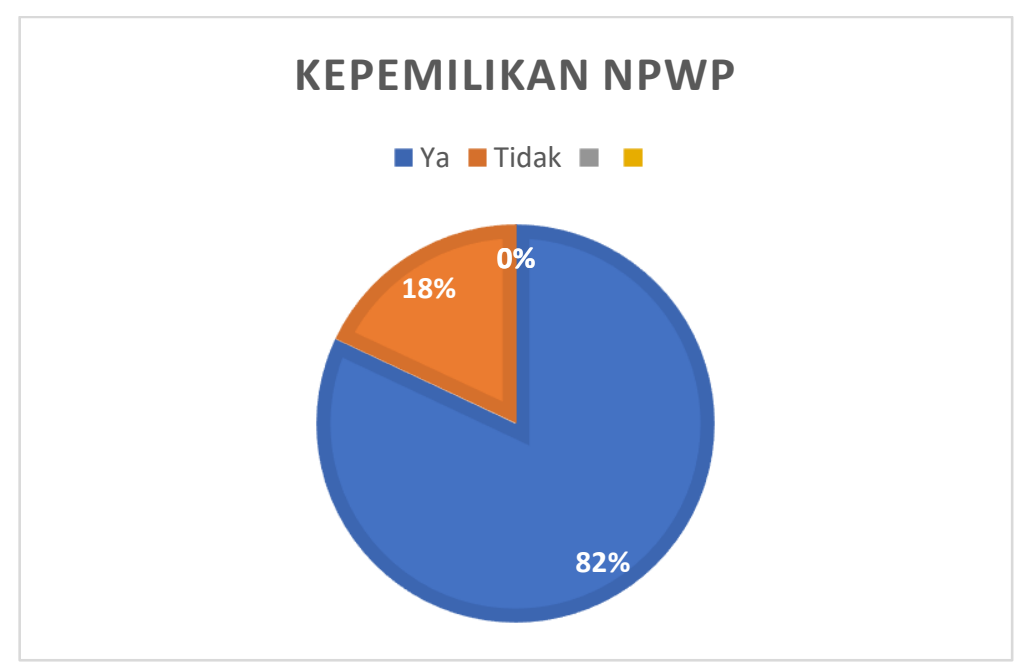

Gambar 4.3. Grafik Karakteristik Responden Berdasarkan Kepemilikan NPWP Sumber : Data Diolah Oleh Penulis, 2019.

Sesuai dengan gambar diatas diketahui bahwa dari 100 responden yang dijadikan sampel, responden yang memiliki NPWP lebih banyak dibandingkan dengan responden yang tidak memiliki NPWP. Responden dengan kepemilikan NPWP yakni sebesar 82 responden atau $82 \%$, dan responden dengan tidak kepemilikan NPWP yakni sebesar 18 responden atau $18 \%$. Hal ini disebabkan karena NPWP saat ini sudah menjadi syarat wajib setiap orang dalam menjalankan usaha atau bisnis, sehingga sebagian besar pelaku e-Commerce sudah memiliki NPWP.

\section{Tingkat Kesadaran Pelaku E-Commerce Rendah Selaku Wajib Pajak}

Kriteria pengambilan keputusan bedasarkan hasil diatas adalah sebagai berikut:

Ho: Tingkat Kesadaran Pelaku E-Commerce Rendah Selaku Wajib Pajak tidak berpengaruh terhadap penghambat pengenaan pajak Penghasilan.

Ha: Tingkat Kesadaran Pelaku E-Commerce Rendah Selaku Wajib Pajak berpengaruh signifikan terhadap penghambat pengenaan pajak Penghasilan.

Jika sig.(probabilitas) $>\alpha(0.05)$, maka Ho diterima dan Ha ditolak

Jika sig. (probabilitas) $<\alpha(0.05)$, maka Ho ditolak dan Ha diterima

Nilai probabilitas $\left(\right.$ Sig. F) $=0.002<0.05$ maka $\mathrm{Ho}_{3}$ ditolak dan $\mathrm{Ha}_{3}$ diterima 
Diketahui nilai thitung lebih besar dari $t_{\text {tabel}},(3.121>1.98525)$ dengan tingkat signifikan 0.002 pada $\alpha=5 \%$ dan nilai signifikan $0.002<0.05$. Hasil ini menunjukkan bahwa secara parsial (individu) variabel Tingkat Kesadaran Pelaku E-Commerce Rendah Selaku Wajib Pajak memiliki pengaruh positif dan signifikan terhadap Penghambat Pengenaan Pajak Penghasilan. Sehingga hipotesis "H1: Tingkat Kesadaran Pelaku ECommerce Rendah Selaku Wajib Pajak berpengaruh signifikan terhadap penghambat pengenaan pajak Penghasilan." diterima.

\section{Pembahasan}

Dari 100 responden, responden yang telah menjadi pelaku $e$-Commerce selama 1-3 tahun yakni sebesar 46 responden atau $46 \%$ telah mendominasi sebagian besar transaksi $e$-Commerce hal itu disebabkan karena transaksi $e$-Commerce pada saat ini lebih mudah dilakukan, sehingga memunculkan ketertarikan orang-orang untuk menjadi pelaku $e$ Commerce. Sementara responden yang telah menjadi pelaku e-Commerce selama $>1$ tahun yakni sebesar 27 responden atau 27\% responden begitu pula untuk pelaku $e$ Commerce selama $>3$ tahun yakni sebesar 27 responden atau 27\%. Dari 100 responden yang dijadikan sampel, responden yang memiliki pendapatan pertahun $<4.8$ Milyar lebih banyak dibandingkan dengan responden yang memiliki pendapatan pertahun $>4.8$ Milyar. Responden dengan pendapatan pertahun $<4.8$ Milyar yakni sebesar 89 responden atau 89 $\%$, dan responden dengan pendapatan pertahun $>4.8$ Milyar yakni sebesar 11 responden atau $11 \%$. Hal ini disebabkan karena transaksi e-Commerce sebagian besar dilakukan secara individual atau perorangan yangmelalui akun media sosial.

Dari 100 responden yang dijadikan sampel, responden yang memiliki NPWP lebih banyak dibandingkan dengan responden yang tidak memiliki NPWP. Responden dengan kepemilikan NPWP yakni sebesar 82 responden atau $82 \%$, dan responden dengan tidak kepemilikan NPWP yakni sebesar 18 responden atau 18\%. Hal ini disebabkan karena NPWP saat ini sudah menjadi syarat wajib setiap orang dalam menjalankan usaha atau bisnis, sehingga sebagian besar pelaku $e$-Commerce sudah memiliki NPWP.

Maka krisis kesadaran pajak pada diri wajib pajak sendiri, wajib pajak merasa membayar pajak adalah sebuah beban yang sangat berat. Hal itu dibuktikan oleh penelitian yang dilakukan oleh Emma (2017), bahwa pelaku e-Commerce berpendapat bahwa pemungutan pajak atas transaksi e-Commerce hanya akan menambah kesemrawutan transaksi jual beli, dikarenakan para penjual harus menghitung, menyetor dan melaporkan setiap transaksi yang mereka lakukan kepada Kantor Pelayanan Pajak setempat. Sehingga sistem pemungutan pajak self assessment system yang dijalankan dalam prakteknya masih sulit dijalankan, hal berikut dapat dilihat dari sikap wajib pajak yang sengaja tidak patuh dan berat melaksanakan kewajiban membayar pajak. Hasil ini sesuai dengan penelitian yang dilakukan oleh Lubis (2016), rendahnya kesadaran dari pelaku e-Commerce selaku wajib pajak menjadi faktor penghambat dalam pengenaan pajak terhadap transaksi e-Commerce.

\section{KESIMPULAN DAN SARAN}

Tingkat Kesadaran Pelaku E-Commerce yang Rendah Selaku Wajib Pajak berpengaruh signifikan terhadap penghambat pengenaan pajak penghasilan karena didapat tingkat signifikan 0.002 pada $\alpha=5 \%$ dan nilai signifikan $0.002<0.05$. Hal itu dapat dilihat dari hasil responden Dari 100 responden yang dijadikan sampel, responden yang memiliki NPWP lebih banyak dibandingkan dengan responden yang tidak memiliki NPWP. 
Responden dengan kepemilikan NPWP yakni sebesar 82 responden atau $82 \%$, dan responden dengan tidak kepemilikan NPWP yakni sebesar 18 responden atau $18 \%$. Hal ini disebabkan karena NPWP saat ini sudah menjadi syarat wajib setiap orang dalam menjalankan usaha atau bisnis, sehingga sebagian besar pelaku e-Commerce sudah memiliki NPWP.

\section{Saran}

Lebih meningkatkan lagi sosialisasi mengenai pentingnya membayar pajak dan tata cara pembayarannya kepada para Pelaku e-Commerce dengan cara lebih aktif lagi membuat kegiatan seminar, penyuluhan, dan juga penataran baik melalui media elektronik atau media massa dan Pihak Direktorat Jenderal Pajak perlu meningkatkan upaya pendataan Pelaku e-Commerce misalnya dengan cara mengecek secara langsung Online Shop yang ada di sosial media atau situs e-Commerce sehingga dapat mengetahui siapa pelaku e-Commerce tersebut karena di dalam akun tersebut biasanya tercantum nomor rekening pihak penjual yang dapat mempermudah untuk mengetahui siapa yang menerima penghasilan tersebut atau pihak DJP dapat memanfaatkan online marketplace untuk mengetahui berapa jumlah pasti transaksi e-Commerce yang terjadi dan juga diperlukan adanya peraturan dan regulasi perpajakan yang jelas dan spesifik, perhatian khusus pada sistem pemungutan pajak yang efektif atas transaksi $e$-Commerce.

\section{DAFTAR PUSTAKA}

Direktorat Jenderal pajak. Peraturan Pemerintah Nomor 23 Tahun 2018 tentang tentang Pajak Penghasilan Atas Penghasilan dari Usaha yang Diterima atau Diperoleh Wajib Pajak yang Memiliki Peredaran Bruto Tertentu. 2018.

Republik Indonesia. (2008). Undang-Undang Nomor 36 Tahun 2008 tentang PerubahanUndang-Undang No. 7 tahun 1984 tentang Pajak Penghasilan (PPh).

Republik Indonesia. (2013). Surat Edaran Direktur Jenderal Pajak Nomor: SE 62/PJ/2013 Tentang Penegasan Ketentuan Perpajakan Atas Transaksi Ecommerce.

Sumarsan T. (2013). Perpajakan Indonesia, Jakarta : PT. Indeks.

Sulistywati, L. (2012). Tiandari. Pengaruh Kesadaran Wajib Pajak, Pelayanan Perpajakan dan Kepatuhan Wajib Pajak terhadap Kinerja Penerimaan Pajak studi kasus pada kantor pelayanan pajak pratama Semarang Candisari. Jurnal Infestasi. Vol 8, PP 81 96.

Suyanto, M. (2003). Strategi Periklanan pada e-Commerce Perusahaan Top Dunia. Yogyakarta: Andi

Tiraada, T. A. (2013). Kesadaran Wajib Pajak, Sanksi Pajak, Sikap FiskusTerhadap Kepatuhan WPOP di Kabupaten Minahasa Selatan. Jurnal EMBA. Volume I; (3), 999-1008)

Waluyo. (2014). Perpajakan Indonesia, Jakarta : Salemba Empat. 